\title{
Effect of Surface Modification on Viability of L929 Cells on Zirconia Nanocomposite Substrat
}

\author{
Moluk Aivazi ${ }^{1 *}$, Mohammadhossein Fathi ${ }^{2}$, Farahnaz Nejatidanesh², Vajihesadat Mortazavi ${ }^{3}$, Batoul Hashemi \\ Beni $^{4}$, Jukka Pekka Matinlinna ${ }^{5}$
}

\begin{abstract}
'Biomaterials Research Group, Department of Materials Engineering, Isfahan University of Technology, Isfahan, Iran ${ }^{2}$ Dental Materials Research Center, Isfahan University of Medical Sciences, Isfahan, Iran

${ }^{3}$ Torabinejad Dental Research Center, Department of Operative Dentistry, School of Dentistry, Isfahan University of Medical Sciences, Isfahan, Iran

${ }^{4}$ Department of Anatomical Sciences and Molecular Biology, School of Medicine, Isfahan University of Medical Sciences, Isfahan, Iran.

${ }^{5}$ Dental Material Science, Head of Unit, Faculty of Dentistry, The University of Hong Kong, 4/FDental Material Science, The Prince Philip Dental Hospital, 34Hospital Road, Sai Ying Pun, Hong Kong
\end{abstract}

\section{*Correspondence to Moluk Aivazi, Biomaterials Research Group, Department of Materials Engineering, Isfahan University of Technology, Isfahan, Iran \\ Tel: +983133912750; \\ Fax: +983133912752 \\ Email: Moluk.Aivazi@gmail.com}

Published online 20 March 2017

\begin{abstract}
Introduction: Zirconia bioceramic can be considered for metallic replacement in dental implant applications. A proper method of surface modification may promote better osseointegration. Methods: In study evaluated viability of fibroblast cell following surface treatment. Therefore, viability L929 cells were characterized using MTT assay and scanning electron microscopy.

Results: The viability assessment determined significant differences A-Y-TZP20 without surface treatment as compared to laser surface treatment (B), laser surface treatment + hydroxyapatiteyttrium stabilized tetragonal zirconia nanocomposite coat $(C)$ and control. This study demonstrated that L929 cells approximately proliferated and spread on A-Y-TZP20 nanocomposite disk in laser surface treatment $(B)$, Laser surface treatment + hydroxiapatite-yttrium stabilized tetragonal zirconia nanocomposite coat $(\mathrm{C})$ groups similar to control group.

Conclusion: Laser surface treatment showed positive effect on the viability of L929 cells.

Keywords: Alumina-yttrium stabilized tetragonal zirconia nanocomposite; Femtosecond laser; MTT assay; Endosseous dental implant.
\end{abstract}

\section{Introduction}

Titanium and its alloys as a dental implant have shown a high successful rate. ${ }^{1}$ Most metals or alloys are prone to corrosion process. Therefore, management and control of corrosion is a crucial point from biological aspects and may not limit to a local problem because the produced particles may migrate to far sites from the implant. Also it is important in terms of biocompatibility. ${ }^{2}$ So, the inert ceramic materials were suggested as alternatives to metals. ${ }^{3}$ Zirconia ceramic has been included in dentistry for different applications. In the design of implant, type of material and surface conditions have an impact on reliable osseointegration. ${ }^{5}$ Also, the degree of roughness is important. The different methods have been used to design the surface roughness. ${ }^{6}$ Beside effects of micro and nanoscale topography on different cells functions have examined in numerous studies. ${ }^{7-13}$ This result has been explained by good cellular behavior. ${ }^{7,10,13,14}$ In vitro and animal studies on zirconia have confirmed good biocompatibility and mechanical strength. ${ }^{15,16}$ The osteoblastic response to different surface topographies of zirconia showed the higher cell proliferation in rough surfaces as compared to the smooth surface. ${ }^{17}$ Therefore the type of modification on morphology and viability L929 on A-Y-TZP20 substrate was evaluated by an invitro method.

\section{Methods}

Deposition of Hydroxyapatite Coating on A-Y-TZP20 Nanocomposite Substrate

The Y-TZP-HA coats were deposited onto A-Y-TZP20 substrates by a dip coating process.

Evaluation of the Surface of A-Y-TZP 20 Nanocomposite Substrates

The studied samples were (A) without any surface 
treatment; (B) femtosecond laser treatment and design microgrooves with $30 \mu \mathrm{m}$ width and $30 \mu \mathrm{m}$ depth, (C) femtosecond laser treatment to design microgrooves with the width of $30 \mu \mathrm{m}$ and the depth of $30 \mu \mathrm{m}$, that were coated using hydroxiapatite-yttrium stabilized tetragonal zirconia polycrystal $(10 \% \mathrm{wt})$ nanocomposite to sol-gel method. ${ }^{18}$ The evaluation of the surface of the nanocomposite disks was assessed.

\section{Cellular Morphology}

The L929 cells were cultured for 5 days on A-Y-TZP20 nanocomposite specimens in control, $\mathrm{A}, \mathrm{B}$ and $\mathrm{C}$ groups and were examined with a scanning electron microscope (Phillips, XL30, the Netherlands).

\section{Colorimetric MTT Assay}

MTT assay was performed on four cultured A-Y-TZP 20 disk substrates (A: non-surface treat, B: femtosecond laser treat, C: laser surface treat $+3 \mathrm{Y}-\mathrm{TZP}-\mathrm{HA}$ nanocomposite coat and D: control groups).

\section{Cell Culture}

The A-Y-TZP 20 nanocomposite disks were sterilized using ultraviolet and ethanol alcohol (70\%). Cell culture studies of L929 were conducted on four groups (A: nonsurface treat, B: laser surface treat, C: laser surface treat + 3Y-TZP-HA nanocomposite coat and control group).

\section{Statistical Analysis}

Kolmogorov-Smirnov test, analysis of variance (ANOVA) test and post hoc analysis were applied. $P<0.05$ was considered as significant.

\section{Results}

Topographic Assessment

In evaluation with scanning electron microscopy, A-YTZP20 with laser micro-texture had laser processing, whereas the A-Y-TZP20 with HA-Y-TZP coat and laser micro-texture surface $(C)$ contained longitudinal and parallel microgrooves that were covered with HA-Y-TZP nanocomposite coat.

\section{Assessment of Cellular Morphology}

The A-Y-TZP20 substrates with 3 different surfaces (A: non-surface treat, $\mathrm{B}$ : laser surface treat, $\mathrm{C}$ : laser surface treat and HA-Y-TZP nanocomposite coat) supported continuous cellular growth for 5 days (Figure 1). After culture, the L929 cells were covered by the surfaces of substrates (A, B and C) and connected with each other (A, B and $C$ ).

\section{Cellular Viability}

Figure 2 shows the optical density in A, B, C and control group in 2 and 5 days incubation. L929 were proliferated on $\mathrm{B}$ and $\mathrm{C}$ disks more than A disks. However, the cellular proliferation on $\mathrm{B}$ and $\mathrm{C}$ disks was almost same as with the control group. The degree of cellular proliferation on B disks group was the highest value. According to ANOVA analysis, and homogeneity of variances (Table 1), the variance of an optical density ( 2 days after incubation $=\mathrm{OD}_{1}$ and 5 days after incubation $=\mathrm{OD}_{2}$ ) variables were significant $\left(\mathrm{OD}_{1}: \mathrm{P} \leq 0.018\right.$ and $\left.\mathrm{OD}_{2}: \mathrm{P} \leq 0.036\right)$. Also, normality distribution of means was significant (Table 2 ). Following significant difference in optical density means and optical density variances in 4 studied groups, post hoc (LSD) test was carried out for comparing of pairwise (Table 3 and Table 4).

\section{Discussion}

A Y-TZP ceramic has suitable biocompatibility, high bending strength and white aesthetic, therefore favour for implant application. ${ }^{19-21}$ Zirconia bioceramic can be considered a proper candidate for metallic replacement in endosseous dental implants. To, A-Y-TZP20 in vivo application, at first can be checked with an in vitro model. The biocompatibility of the materials depends on their physical, chemical and the first response of the cells on surface properties. Also, the interaction of the cells

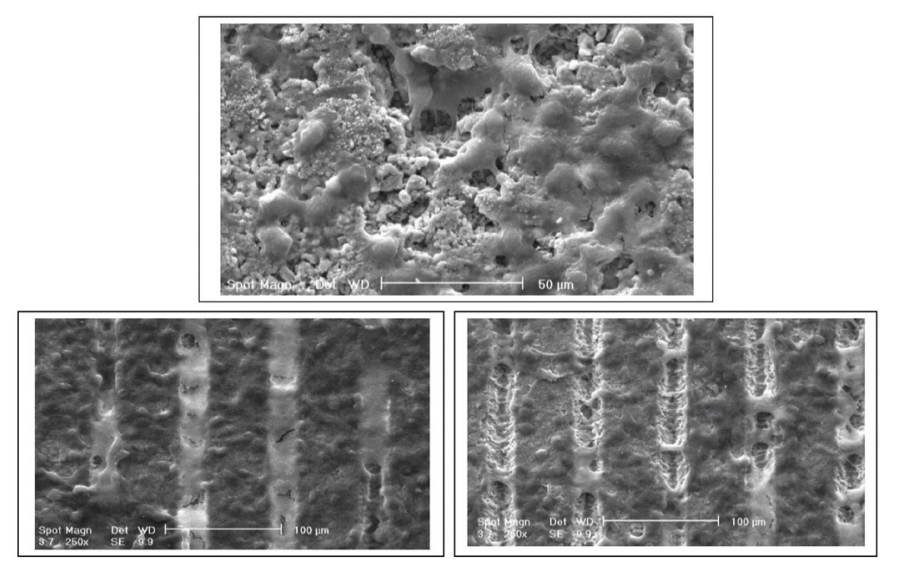

Figure 1. The SEM images of L929 cells on the surface of A-3-Y-TZP nanocomposite disk in A: non-surface treat, B: femtosecond laser treat, C: femtosecond laser + HA-3Y-TZP nanocomposite coat treat and control (D) groups 5 days after cell culture. 

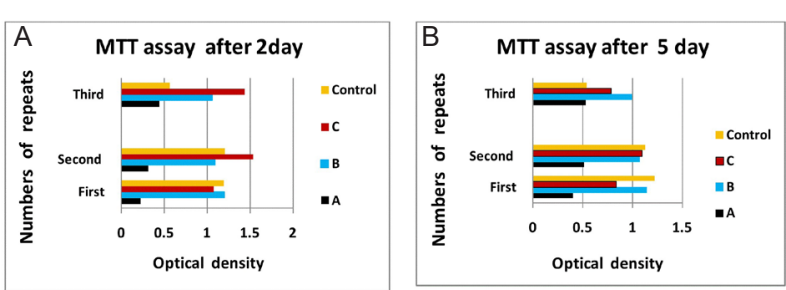

Figure 2. The results of MTT assay in A: non-surface treat, B: femtosecond laser treat, C: femtosecond laser +HA-3Y-TZP nanocomposite coat treat and control (D) groups at 2 and 5 days after incubation.

Table 1. The Results of the Homogeneity of Variances Test at 2 (OD1) and 5 days (OD2) After Incubation

\begin{tabular}{lcccc}
\hline Optical Density (OD) & Levene Test & $\boldsymbol{d f}_{\boldsymbol{1}}$ & $\boldsymbol{d f}_{\boldsymbol{2}}$ & $\boldsymbol{P}$ \\
\hline $\mathrm{OD}_{1}: 2 \mathrm{~d}$ after incubation $(\mathrm{n}=6)$ & 4.694 & 3 & 8 & $0.036^{\mathrm{a}}$ \\
$\mathrm{OD}_{2}: 5 \mathrm{~d}$ after incubation $(\mathrm{n}=6)$ & 6.094 & 3 & 8 & $0.018^{\mathrm{a}}$ \\
\hline
\end{tabular}

a $P$ value is significant at the level of $<0.05$.

with the material surface is important for contributing to osseointegration. ${ }^{22}$ On the other hand, an implant morphology affect bone metabolism: rougher surfaces motivate differentiation, growth and attachment of bone cells, and increase mineralization. The different methods were reported in the literature to design implant roughness. Recently, the surface modification of implant is considered using of femtosecond laser. The microtexture specially groovy pattern was more effective than pored patterns. ${ }^{23}$ Therefore, the morphology and viability of L929 cells on three different surface of A-YTZP20 substrate was evaluated (A: non surface treat, B: laser surface treat, C: laser surface treat and HA-YTZP (10\%wt) nano-composite coat). All the substrates in this study were A-Y-TZP20 nanocomposite disk but their surfaces were different. In microstructure analysis, dense nanocomposite (Figure $3 \mathrm{~A}$ ) was visible. In EDAX analysis (Figure 3B, 3C) and mapping of $\mathrm{x}$-ray (Figure 3D) proved nanopowders in nanocomposite. Figure 5A show the modified surface with femtosecond laser. Longitudinal microgrooved pattern with specific dimension is evident in nano-composite surface. Figure $5 \mathrm{~B}$ and Figure $5 \mathrm{C}$ show a view of an one groove that was designed using femtosecond laser on nano-composite surface but in Figure 5C, the microgroove was covered by nano-composite coat (hydroxyapatite-yttrium-stabilized tetragonal zirconia polycrystal). As it is clear from Figure
Table 3. The Result of Post Hoc Analysis at 2 Days After Incubation Between Studied Groups ${ }^{\text {b }}$

\begin{tabular}{llll}
\hline Dependent Variable & (J) Group & (I) Group & $\boldsymbol{P}$ \\
\hline & & B & $0.003^{\mathrm{a}}$ \\
& A & C & $0.001^{\mathrm{a}}$ \\
& & D & $0.008^{\mathrm{a}}$ \\
& & A & $0.003^{\mathrm{a}}$ \\
OD $_{1}$ (after 2 days) & B & C & 0.239 \\
No. of samples per & & D & 0.527 \\
each group =6 & A & C & $0.001^{\mathrm{a}}$ \\
& & B & 0.239 \\
& & D & 0.089 \\
& A & D & $0.008^{\mathrm{a}}$ \\
& & B & 0.527 \\
\hline
\end{tabular}

${ }^{a} P$ value is significant at the level of $<0.05$.

${ }^{\mathrm{b}} \mathrm{A}$ : non-surface treat, B: laser surface treat, C: laser surface treat + Y-TZP-

HA nanocomposite coat and D: control.

Table 4. The Result of Post Hoc Analysis at 5 Days After Incubation Between Studied Groups ${ }^{\mathrm{b}}$

\begin{tabular}{|c|c|c|c|}
\hline Dependent Variable & (J) Group & (I) Group & $P$ \\
\hline \multirow{6}{*}{$\mathrm{OD}_{2}$ (after 5 days) } & \multirow{3}{*}{ A } & B & $0.008^{\mathrm{a}}$ \\
\hline & & $\mathrm{C}$ & $0.035^{a}$ \\
\hline & & $\mathrm{D}$ & $0.022^{\mathrm{a}}$ \\
\hline & \multirow{3}{*}{ B } & A & $0.008^{a}$ \\
\hline & & $\mathrm{C}$ & 0.377 \\
\hline & & $\mathrm{D}$ & 0.540 \\
\hline \multirow{6}{*}{$\begin{array}{l}\text { No. of samples per } \\
\text { each group }=6\end{array}$} & \multirow{3}{*}{$\mathrm{C}$} & A & $0.035^{\mathrm{a}}$ \\
\hline & & B & 0.377 \\
\hline & & $\mathrm{D}$ & 0.776 \\
\hline & \multirow{3}{*}{$\mathrm{D}$} & A & $0.022^{\mathrm{a}}$ \\
\hline & & B & 0.540 \\
\hline & & $\mathrm{C}$ & 0.776 \\
\hline
\end{tabular}

a $P$ value is significant at the level of $<0.05$.

${ }^{\mathrm{b}} \mathrm{A}$ : non-surface treat, $\mathrm{B}$ : laser surface treat, C: laser surface treat $+\mathrm{Y}-\mathrm{TZP}-$

HA nanocomposite coat and D: control.

$5 \mathrm{~B}$ the walls of groove is regular and without any crack. In present study and MTT assay after 2 day (Figure 2A) in laser surface treat group (B), laser surface treat+HAY-TZP nanocomposite coat $(\mathrm{C})$ and control groups, the optical density was higher than non-surface treat (A). Also, in post hoc analysis and pairwise comparison of means (Table 3 ) were only significant non-surface treat (A group) with the other groups $(P \leq 0.05)$. Also, MTT assay after 5 day (Figure $2 \mathrm{~B}$ ) the optical density in nonsurface treat $(\mathrm{A})$ showed the lowest value between studied

Table 2. The Results of ANOVA Analysis at 2 (OD1) and 12 Hours (OD2) After Incubation

\begin{tabular}{|c|c|c|c|c|c|c|}
\hline Optical Density (OD) & & Sum of Squares & $d f$ & Mean Square & $\boldsymbol{F}$ & $P$ \\
\hline \multirow{2}{*}{$\mathrm{OD}_{1}: 2 \mathrm{~d}$ after incubation $(\mathrm{n}=6)$} & Between groups & 1.727 & 3 & 0.576 & \multirow{2}{*}{10.898} & \multirow{2}{*}{$0.003^{\mathrm{a}}$} \\
\hline & Within groups & 0.423 & 8 & 0.053 & & \\
\hline \multirow{2}{*}{$\mathrm{OD}_{2}: 5 \mathrm{~d}$ after incubation $(\mathrm{n}=6)$} & Between groups & 0.602 & 3 & 201 & \multirow{2}{*}{4.640} & \multirow{2}{*}{$0.037^{\mathrm{a}}$} \\
\hline & Within groups & 0.346 & 8 & 0.43 & & \\
\hline
\end{tabular}

a $P$ value is significant at the level of $<0.05$. 

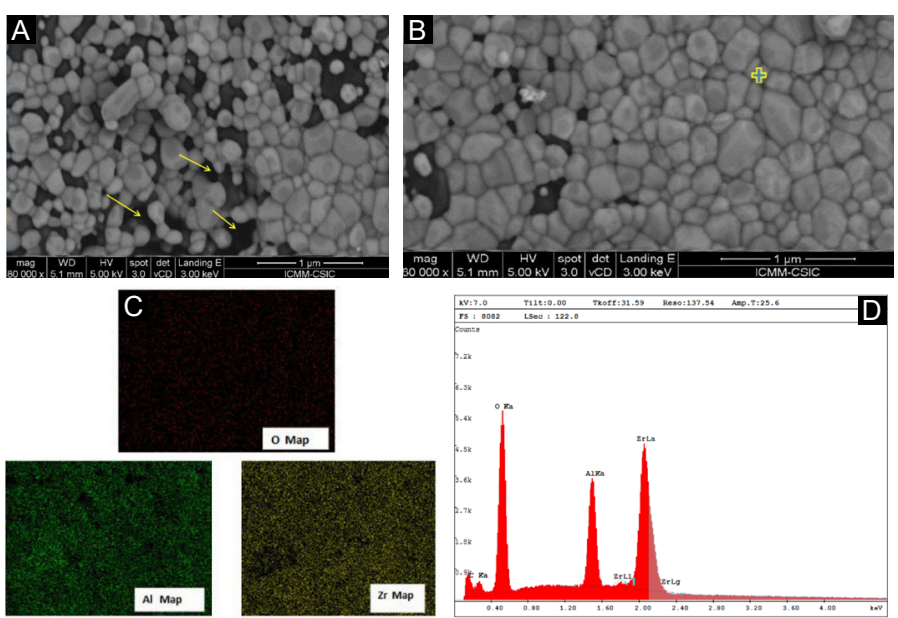

Figure 3. (A) The FESEM image from A-3Y-TZP20 nanocomposite. (B) The FESEM image from A-3Y-TZP20 nanocomposite sintered at $1270^{\circ} \mathrm{C}$. (C) EDAX analysis of A-3Y-TZP20 nanocomposite sintered at $1270^{\circ} \mathrm{C}$. (D) X- ray mapping from A-3Y-TZP20 nanocomposite sintered at $1270^{\circ} \mathrm{C}$.
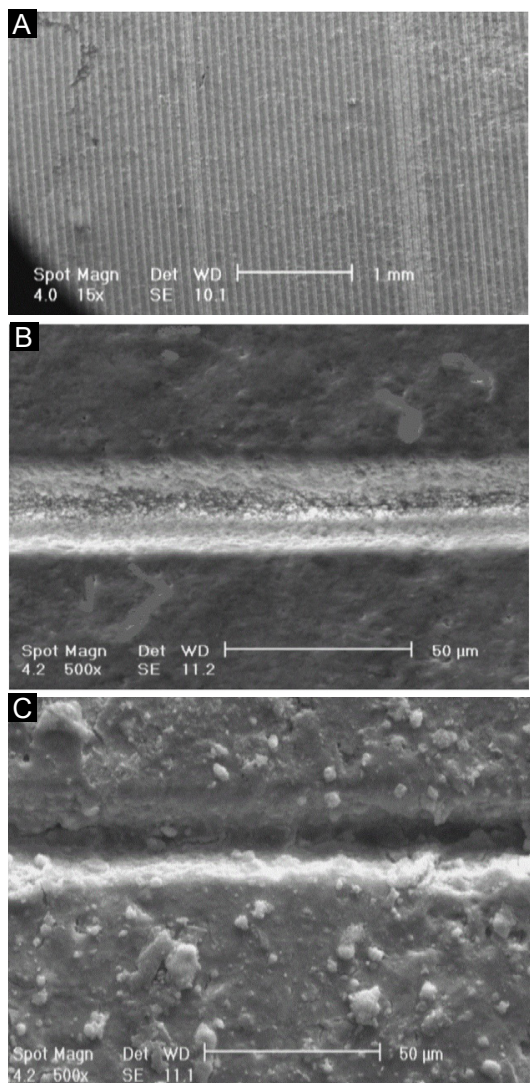

Figure 4. The SEM image of microgroove pattern on A-3YTZP20 nano-composite disk after laser processing disk and one microgroove without (B) and with (C) HA-3-Y-TZP nanocomposite coat.

groups. In post hoc analysis and multiple comparison of means (Table 4) merely the non-surface treat (A group) with the other groups were significant $(P \leq 0.05)$. But in comparison of $\mathrm{B}, \mathrm{C}$ and control group no significant differences were observed. It seemed, therefore that, the surface treatment had significant effect on optical density.
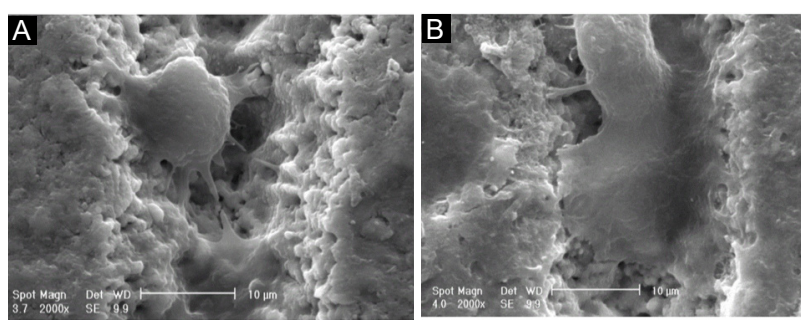

Figure 5. The SEM image of femtosecond laser treatment group Band L929 cell morphology in the depth of microgroove (A) and in the surface of microgroove (B) 5 day after cell culture.

So that, the optical density in non-surface treat group at 2 different times repeated three times were the lowest value among the studied groups. Although, the significant difference was not observed between $\mathrm{B}$ and $\mathrm{C}$ group. It seems, more studies are needed on 2 different modified surface especially comparison of osteoblast cells with L929 cells is proposed. In present study, surface modification procedures had maximally influence the proliferative behavior of L929 cells. The cellular proliferation and density in $\mathrm{B}$ and $\mathrm{C}$ groups, were approximately similar to control group. Day 5 cultures showed a lower density of L929 cell in non-surface treat Figure 4A than B and $\mathrm{C}$ groups. These findings were confirmed via SEM image analysis. Based on SEM image analysis, at day 5, the coverage rate of the L929 cells in non-surface treatment was lower than $\mathrm{B}$ and $\mathrm{C}$ groups (Figure 1). It was suggested that these surfaces ( $B$ and $C$ groups) provided good conditions for the L929 cells growth. In A and B substrate groups evident a more growth of fibroblasts. It seemed, the modification of substrate topography promoted cell spreading, this result in increased mitosis and cellular proliferation. Also, in microgroove region can be seen the cells morphology in the depth of microgroove round (Figure 5) but proximal edges (Figure 5) of microgroove 
is flattened with the extended numerous filopodia. Based on this study L929 cells proliferated and spread approximately in laser surface treat (group B) and laser surface treat + HA-Y-TZP nanocomposite coat (group C) similar to control group.

\section{Conclusion}

The cell proliferation of laser surface treatment (B) and laser surface treatment + hydroxyapatite-yttrium stabilized tetragonal zirconia nanocomposite coat (C) groups were comparable to the control group. The surface treatment of both laser surface treatment (B) and laser surface treatment + hydroxyapatite-yttrium stabilized tetragonal zirconia nanocomposite coat (C) was influenced the viability of the L929 cells, like to control group. The specimens with surface treatment (B and C groups) had better MTT result as compared to the nonsurface treat (A group). Finally laser surface treatment showed a positive effect on the viability of L929 cells.

\section{Conflict of Interests}

The authors declare no conflict of interest.

\section{Ethical Considerations}

Not applicable.

\section{Acknowledgements}

We would like to thank Professor Jukka for scientific supports and cooperation.

\section{References}

1. Yamashita D, Machigashira M, Miyamoto M, et al. Effect of surface roughness on initial responses of osteoblast-like cells on two types of zirconia. Dent Mater J. 2009;28(4):461470.

2. Olmedo DG, Tasat DR, Duffo G, Guglielmotti MB, Cabrini RL. The issue of corrosion in dental implants: a review. Acta Odontol Latinoam. 2009;22(1):3-9.

3. Gehrke P, Dhom G, Brunner J, Wolf D, Degidi M, Piattelli A. Zirconium implant abutments: fracture strength and influence of cyclic loading on retaining-screw loosening. Quintessence Int. 2006;37(1):19-26.

4. Kelly JR, Denry I. Stabilized zirconia as a structural ceramic: an overview. Dent Mater. 2008;24(3):289-298. doi:10.1016/j.dental.2007.05.005

5. Albrektsson T, Branemark PI, Hansson HA, Lindstrom J. Osseointegrated titanium implants. Requirements for ensuring a long-lasting, direct bone-to-implant anchorage in man. Acta Orthop Scand. 1981;52(2):155-170.

6. Novaes AB, Jr., de Souza SL, de Barros RR, Pereira KK, Iezzi G, Piattelli A. Influence of implant surfaces on osseointegration. Braz Dent J. 2010;21(6):471-481.

7. Christenson EM, Anseth KS, van den Beucken JJ, et al. Nanobiomaterial applications in orthopedics. J Orthop Res. 2007;25(1):11-22. doi:10.1002/jor.20305

8. Bacakova L, Stary V, Kofronova O, Lisa V. Polishing and coating carbon fiber-reinforced carbon composites with a carbon-titanium layer enhances adhesion and growth of osteoblast-like MG63 cells and vascular smooth muscle cells in vitro. J Biomed Mater Res. 2001;54(4):567-578.

9. Khang D, Lu J, Yao C, Haberstroh KM, Webster TJ. The role of nanometer and sub-micron surface features on vascular and bone cell adhesion on titanium. Biomaterials. 2008;29(8):970-983. doi:10.1016/j.biomaterials.2007.11.009

10. Liu H, Yazici H, Ergun C, Webster TJ, Bermek H. An in vitro evaluation of the $\mathrm{Ca} / \mathrm{P}$ ratio for the cytocompatibility of nano-to-micron particulate calcium phosphates for bone regeneration. Acta Biomater. 2008;4(5):1472-1479. doi:10.1016/j.actbio.2008.02.025

11. Mendonca G, Mendonca DB, Aragao FJ, Cooper LF. Advancingdentalimplantsurfacetechnology--frommicronto nanotopography. Biomaterials. 2008;29(28):3822-3835. doi:10.1016/j.biomaterials.2008.05.012

12. Webster TJ, Ergun C, Doremus RH, Siegel RW, Bizios R. Enhanced functions of osteoblasts on nanophase ceramics. Biomaterials. 2000;21(17):1803-1810.

13. Zhao G, Raines AL, Wieland M, Schwartz Z, Boyan BD. Requirementforboth micron-and submicronscale structure for synergistic responses of osteoblasts to substrate surface energy and topography. Biomaterials. 2007;28(18):28212829. doi:10.1016/j.biomaterials.2007.02.024

14. Webster TJ, Ergun C, Doremus RH, Siegel RW, Bizios R. Specific proteins mediate enhanced osteoblast adhesion on nanophase ceramics. J Biomed Mater Res. 2000;51(3):475483.

15. Dubruille JH, Viguier E, Le Naour G, Dubruille MT, Auriol M, Le Charpentier Y. Evaluation of combinations of titanium, zirconia, and alumina implants with 2 bone fillers in the dog. Int J Oral Maxillofac Implants. 1999;14(2):271277.

16. Scarano A, Di Carlo F, Quaranta M, Piattelli A. Bone response to zirconia ceramic implants: an experimental study in rabbits. J Oral Implantol. 2003;29(1):8-12. doi:10.1563/1548-1336(2003)029<0008:brtzci>2.3.co;2

17. Bachle M, Butz F, Hubner U, Bakalinis E, Kohal RJ. Behavior of CAL72 osteoblast-like cells cultured on zirconia ceramics with different surface topographies. Clin Oral Implants Res. 2007;18(1):53-59. doi:10.1111/j.16000501.2006.01292.x

18. Fathi MH, Hanifi A. Sol-gel derived nanostructure hydroxyapatite powder and coating: aging time optimisation. Advances in Applied Ceramics. 2009;108(6):363-368. doi:10.1179/174367609X414080

19. Kohal RJ, Att W, Bachle M, Butz F. Ceramic abutments and ceramic oral implants. An update. Periodontol 2000. 2008;47:224-243. doi:10.1111/j.1600-0757.2007.00243.x

20. Nakamura K, Kanno T, Milleding P, Ortengren U. Zirconia as a dental implant abutment material: a systematic review. Int J Prosthodont. 2010;23(4):299-309.

21. Ekfeldt A, Furst B, Carlsson GE. Zirconia abutments for single-toothimplant restorations: a retrospective and clinical follow-up study. Clin Oral Implants Res. 2011;22(11):13081314. doi:10.1111/j.1600-0501.2010.02114.x

22. Nebe B, Forster C, Pommerenke $\mathrm{H}$, et al. Structural alterations of adhesion mediating components in cells cultured on poly-beta-hydroxy butyric acid. Biomaterials. 2001;22(17):2425-2434.

23. Delgado-Ruiz RA, Calvo-Guirado JL, Moreno P, et al. Femtosecond laser microstructuring of zirconia dental implants. J Biomed Mater Res B Appl Biomater. 2011;96(1):91-100. doi:10.1002/jbm.b.31743 